Ethiopian Journal of Environmental Studies \& Management 7(6): 645 - 653, 2014.

ISSN:1998-0507

doi:http://dx.doi.org/10.4314/ejesm.v7i6.7

Submitted: July 25, 2014

Accepted: October 11, 2014

\title{
COMMUNITY SOCIAL INSECURITY: AN ENVIRONMENTAL DEGRADATION INDUCED PROBLEM IN THE NIGER DELTA, NIGERIA
}

\author{
AKINBAMI, S.O. AND *ABIONA, I.A.
}

Department of Adult Education, University of Ibadan, Ibadan

\begin{abstract}
This study, therefore investigated the effects of NDDC's programme in alleviation of community social insecurity in the two oil producing states. The descriptive survey research design was adopted for the study. In each state, five communities were purposively selected from Edo and Ondo States. Random sampling procedure was used to select 3212 respondents from the two States. Data were collected using the Niger Delta Project Community Assessment Scale (NDPCAS), ( $r=0.82)$ and NDDC Projects Implementation Scale, $(r=0.66)$. The survey was complemented with Focus Group Discussions (FGD).Two research questions were answered and data were analyzed using frequency counts, percentages and mean analysis. The FGD results revealed that most of the facilities claimed to have been put in place by the NDDC were nonexistent. Inadequate consultations with beneficiaries of the programmes hindered the NDDC in the delivery of its programmes. The NDDC programmes were ineffective in the reduction of social tension (69.2\%), violence and crime (69.5\%). The NDDC programmes and facilities did not contribute significantly to the development of the oil producing communities of Edo and Ondo States. It is recommended that the NDDC should adopt an integrated participatory approach in the design of its projects for the effectiveness of its programmes.
\end{abstract}

Key Words: Empowerment, Poverty alleviation, insecurity, programme, beneficiaries, environmental- degradation

\section{Introduction}

The economy of Nigeria had predominantly been agriculturally based until crude oil was discovered in commercial quantity in Oloibiri, Rivers State in 1956. (Turcotte, 2002). This transformed the nation's focus from agriculture to crude oil production. Obadan (2004), commenting on the state of the Nigerian economy, explained that before the oil boom of the 1970s, agriculture was the mainstay of Nigeria's economy accounting for two-thirds of the Gross Domestic Product (GDP), about twothirds of labour employment, substantial supply of raw materials for industries and large production of non-oil export earnings.
With time, however, petroleum became increasingly more significant, culminating in a boom in the 1970s that led to the relegation of agriculture and its contribution to the national economy. Nigerian crude oil and gas deposits are predominantly found in the area known today as the Niger Delta Region. According to the Niger Delta Development Commission (NDDC) (2003), the Niger Delta Region comprises of nine states of the Federation, namely, Abia, Akwa Ibom, Bayelsa, Cross-River, Delta, Edo, Imo, Ondo and Rivers States.

In addition to the problem of poverty, there are cases of environmental degradation in the region as a result of petroleum 
exploration, exploitation, refining, transportation, storage and marketing (Okonya et al., 1988). Olaifa (2003) also asserted that drill cuttings, drilling mud (fluids for stimulating the oil production processes), and accidental discharges of crude oil take place during exploration and exploitation processes culminating into serious water pollution in the oil producing areas of the Niger Delta. These accidental spills include petrol, lubricating oil, diesel, sludge and bitumen slop (Nigerian Environmental Study/Team, 1991). Between 1976 and 1997, Nigeria recorded about five thousand, three hundred and thirty four $(5,334)$ spill incidents involving 2.8 million barrels of oil released into land, swamp, estuaries and coastal waters of the Niger Delta (Dublin-Green et al, 1998). The Obagi oil field spill (1980), Funiwa oil well blow out (1980) and the Mobil oil spill (1998) are among some of the major accidental oil spill incidents recorded in the Nigerian oil industry. According to Bassey and Obari (1998), the Mobil oil spill was caused by a burst pipeline linking Idoho platform and Eket and involved 40,000 barrels of light crude oil. The Jesse pipeline (1999) devastation and Atlas Cove (Lagos) tragedies of 2000 resulted into the loss of several lives and the destruction of the environment by explosion and fire. Shell Petroleum Development Corporation (2004) (SPDC) also reported that the incidents of sabotage arising from the vandalism of facilities in their areas of operation were on the increase. One of such recent incidents according to the SPDC (2004) was the damage to the Trans Niger Pipeline in Gokana Local Government Area of Rivers State on the $10^{\text {th }}$ of October, 2004 whereby an estimated 150 barrels of crude were spilt.

SPDC (2004) further explained that in 2003 alone, 211 oil spill incidents with spill volumes of some 9900 barrels were recorded.
Nearly two-thirds of these, i.e. 141 incidents were caused by wilful damage to facilities accounting for 6730 barrels of oil, $68 \%$ of total volume of oil spills. These oil spill incidents have resulted in the waters of the creeks becoming turbid with crude oil killing the aquatic life on which the livelihoods of the people mainly rest thereby leading to social insecurity.

Okonya et al., (1988) revealed that marshland on which fishes and shrimps depend for survival are devastated by crude oil spillages which in turn destroy the fishing occupation of the people. Thus, the primary occupations of the people which are farming and fishing are being wiped out by the environmental degradation activities of the oil industry thereby rendering the people jobless, poor and angry. From Warri to Ibeno, the people cannot farm or fish because of oil spillage and pollution. They can hardly drink potable water and their health is in severe jeopardy.

The multi-national companies and government have exploited the ecosystem for resources beyond the level of sustainability thus creating an ecological problem for the Niger Delta (Ashton Jones, 1998). Thus Azaiki (2003) commented further that the Niger Delta people have continued to live with a range of environmental problems ranging from health hazards to lack of safe water and shortage of arable land because of the toxicity of crude oil to most species of plant and animal when it is spilt. Inspite of the region's resource endowment and its immense potential for economic growth and sustainable development, the region remains in a parlous state. It is under the threat of rapidly deteriorating economic conditions and social tension and insecurity.

Consequent upon the environmental degradation, social disruption, endemic rate of poverty and high unemployment particularly among the millions of restive 
youths, a hostile relationship ensued between the oil companies and the people of the region. This has often resulted into violent demonstrations, kidnapping of expatriate staff of the oil companies and at times murder, destruction of properties, vandalism of oil pipelines resulting into deliberate oil spillages and other crimes. Natural resourcesbased conflicts resulting from the struggle for access, control, use and ownership of resources, primarily crude oil and gas, are rampant (Kimani, 2004)

Over the years, resource exploration, environmental pollution and the mode and means of appropriation of the revenue derived from oil have generated intense social conflict. Poverty, social dislocation and poor infrastructural development have compounded the critical issue of sustainability of the region (Chokor, 1992; 1993). Obadan (2004) argued that for Nigeria to move forward, there must be political stability. Current instability, he argued, had been occasioned amongst other reasons by ethnic violence in the Niger Delta region.

This study, therefore, evaluated the effectiveness of the NDDC's programmes aimed at ameliorating the region's problems of social insecurity, crime and unrest using Edo and Ondo states' oil producing communities as the scope of the study.

\section{Objectives of Study}

The objectives of this study include:

(a) to ascertain the extent to which social instability, violence and crime have reduced in the two states since the inception of the NDDC.

(b) to find out whether the beneficiaries have been involved in the determination of their felt needs through planning and implementation of the programmes.

\section{Research Questions}

The following research questions are answered:
To what extent have the NDDC programmes led to the reduction of violence, crime and social instability in the two states?

To what extent have the beneficiaries been involved in the determination of their felt needs through planning and implementation of the programmes?

\section{Methodology}

The research design adopted for this study was the descriptive survey. This study adopted the multi-stage sampling procedure comprising the purposive, stratified and proportionate random sampling techniques respectively. The purposive sampling was used to select five communities each from Edo and Ondo states. The stratified sampling technique was then used to divide the population into strata namely: community leaders, men, women and youths. Finally, the researchers adopted the simple random and proportionate sampling technique to select 3213 respondents that were needed for the study as shown in Tables 1 and 2. The major instrument used for data collection was the "NDDC Project Community Assessment Questionnaire" (NPCAQ). This was complemented with the Focus Group Discussion (FGD) and In-depth Interviews with key informants (IDIs). The secondary source of information was an official document from the NDDC.

To establish the reliability of the instrument, a pilot study was conducted using a sample of 200 randomly selected respondents from two (2) communities that though shared the same characteristics with the population of interest, do not form part of the study sample. Data obtained were then analysed using the Cronbach's coefficient of alpha. This yielded a reliability index of 0.79 .

Data collected were analysed using frequency counts, percentages, mean and standard deviations analysis. The FGD and IDI information were analysed qualitatively. 
Table 1: Distribution of Sample Size of Communities in Edo State

\begin{tabular}{llll}
\hline S/N & Names of Communities & Population & Sample Size (5\%) \\
\hline 1 & Evbokabua & 2,522 & 126 \\
2 & Ologbo & 10,022 & 501 \\
3 & Ugboko-Niro & 1,902 & 95 \\
4 & Ugboton & 475 & 24 \\
5 & Ugo & 5,961 & 298 \\
Total & & 20882 & 1044 \\
\hline
\end{tabular}

Source: National Population Census 1991

Table 2: Distribution of Sample Size of Communities in Ondo State

\begin{tabular}{llll}
\hline S/N & Names of Communities & Population & Sample Size (5\%) \\
\hline 1 & Aiyetoro & 14,521 & 726 \\
2 & Igbokoda & 10,245 & 512 \\
3 & Ilepete & 8,476 & 424 \\
4 & Orioke Iwa Mimo & 3,785 & 189 \\
5 & Ugbonla & 6,365 & 318 \\
Total & & 43392 & 2169 \\
\hline
\end{tabular}

Source: National Population Census 1991

\section{Results and Discussion}

Research Question 1: To what extent have the NDDC programmes led to the reduction of violence, crime and social instability in the two states?

Tables 3 and 4 below supply us the relevant data to answer the research question.

Table 3 showing respondents' assessment of effect of NDDC programmes vis-à-vis reduction of crime and violence in the two states

\begin{tabular}{|l|l|l|}
\hline & Frequency & Percentage \\
\hline SD & 745 & 23.2 \\
D & 1490 & 46.4 \\
A & 629 & 19.6 \\
SA & 349 & 10.9 \\
\hline Total & 3212 & 100.0 \\
\hline
\end{tabular}

Table 4 showing respondents' assessment of the effect of NDDC programmes vis-à-vis the reduction of social tension in the two states

\begin{tabular}{|l|l|l|}
\hline & Frequency & Percentage \\
\hline SD & 676 & 21.0 \\
D & 1549 & 48.2 \\
A & 651 & 20.3 \\
SA & 337 & 10.5 \\
\hline Total & 3212 & 100.0 \\
\hline
\end{tabular}

From the two tables above, it could be deduced that the NDDC programmes have not brought the expected social stability to the areas. Most of the respondents stated that the programmes have not reduced the social tension in the areas. Table 3 clearly showed that the majority of the respondents, 69.6 percent, disagreed that the NDDC programmes had led to the reduction of crime and violence. 
Table 5 below supply more information about the prevailing indicators of social instability in the two states as discovered through the FGD and IDI conducted during the fieldwork.

Table 5: Perceived Indicators of Social Instability in the two states

\begin{tabular}{|l|l|}
\hline S/N & Categories \\
\hline 1. & Prevalence of Crime and violence, \\
2. & Unhealthy rivalry amongst the ethnic groups, \\
3. & Unemployment amongst the teeming youth, \\
4. & Lack of accessibility to schools and schooling, \\
5. & Lack of accessibility to medical facilities and health care delivery, \\
6. & Corruption of NDDC officials. \\
\hline
\end{tabular}

Research Question 2: To what extent have the beneficiaries been involved in the determination of their felt needs through planning and implementation of the programmes?

Table 6: Beneficiaries' involvement in determination of NDDC's programmes for sustainable development

\begin{tabular}{llllll}
\hline S/N & Item on instrument & Yes & \multicolumn{2}{l}{ No } & \\
\hline $\begin{array}{l}\text { Was the choice of the project in your } \\
\text { community decided by NDDC alone? }\end{array}$ & Freq & $\%$ & Freq & $\%$ \\
$\begin{array}{l}\text { Are you participating in the } \\
\text { implementation }\end{array}$ & 430 & 22.7 & 1093 & 34.0 \\
$\begin{array}{l}\text { Do you see the project in your area as } \\
\text { "their own" (yes), or our own"? (no) }\end{array}$ & & 64.9 & 531 & 16.5 \\
\hline
\end{tabular}

Table 7 Beneficiaries level of participation in NDDC Programmes implementation.

\begin{tabular}{|c|c|c|c|c|c|c|c|c|}
\hline Level of implementation of: & Never & & Rarel & & Occa & onally & Alw & \\
\hline & $\mathrm{F}$ & $\%$ & $\mathrm{~F}$ & $\%$ & $F$ & $\%$ & $\mathrm{~F}$ & $\%$ \\
\hline Initiation of project idea & 1251 & 38.9 & 880 & 27.4 & 625 & 19.5 & 457 & 14.2 \\
\hline $\begin{array}{l}\text { Publicity to win public } \\
\text { support }\end{array}$ & 854 & 26.6 & 773 & 24.1 & 918 & 28.6 & 668 & 20.8 \\
\hline $\begin{array}{l}\text { Membership of } \\
\text { implementation committee }\end{array}$ & 1294 & 40.3 & 7764 & 23.8 & 660 & 20.5 & 495 & 15.4 \\
\hline Physical executive of work & 1055 & 32.8 & 601 & 18.7 & 863 & 26.9 & 694 & 21.6 \\
\hline $\begin{array}{l}\text { Soliciting for financial, } \\
\text { material and communal } \\
\text { support }\end{array}$ & 1209 & 37.6 & 548 & 17.1 & 964 & 30.0 & 492 & 15.3 \\
\hline
\end{tabular}

The information that was used in the answering this research question is provided in Table 6 showed that only 14.8 percent of the respondents participated in the determination of the projects of the NDDC in their communities while 44 percent said that the choice of the projects was decided solely by the NDDC. This explained why 34.0 percent of the respondents indicated that they were neither involved nor participated in the implementation of the NDDC projects as against 22.7 percent that indicated that they were participating in the project implementation. Also 64.9 percent respondents saw the projects as "their own" meaning that of the NDDC alone while only 
16.5 percent of the respondents indentified with the projects.

Table 7 showed further with reference to publicity to winning public support; the level of participation of the people was better. 20.8 percent of the respondents indicated that they always participated in canvassing for public support for the NDDC programmes, while 28.6 percent said that they had never participated in publicizing the NDDC prorgammes of development and 24.1 percent said that they rarely did publicize the programmes. A clear inference from the above data showed that the level of participation of the people in terms of giving adequate publicity to the NDDC programmes of sustainable development was high.

However, with regards to being members of implementation committee of the NDDC programmers, Table 7 showed that the level of participation of the people was rather low. This is seen from the fact that only 15.4 percent of the respondents indicated that they always participated in implementation committees. 20.5 percent said they occasionally did while 40.3 percent of the respondents indicated that they had never been members of the implementation committee, and 23.8 percent agreed that they rarely participated in such committee.

The results from Research Question One showed that the acute shortage of developmental projects being implemented by the NDDC had led to a situation of unhealthy rivalry amongst the ethnic groups who engage in several manoeuvring schemes to sideline or eliminate the competitive demands of their co-ethnic groups for the few developmental projects brought by the NDDC. Also according to Table 4, 69.2 percent of the respondents either disagreed or strongly disagreed with the view that the NDDC programmes had led to a reduction of social tension in the two states.
The failure of the NDDC to provide these programmes of development had resulted into an acute shortage of medical facilities and access to health care provision. Accessibility to schools and schooling is also greatly impaired. Unemployment is rampant amongst the teeming youths. On the whole, unemployment is still very much prevalent. The inability of most of the respondents to benefit from economic empowerment programmes of the NDDC had led to a prevalence of crime and violence in the area. This is in accordance with the adage that says 'an idle hand is the devil's workshop'.

During the field work, FGD and IDI conducted revealed a plethora of felt needs of the people which were not contained in the NDDC's programme for sustainable development of the region. It was discovered, for example, that the number one felt need of the people of Aiyetoro in Ondo State is how to control the dangerous incursion activities of the ocean on their community. Anxiety of the people of the community is palpable. In Ugbonla, Ondo State for example, the people were worried also about the erosion of their sea shores and urgently required embankment programmes to allay their fears. The lack of the consideration and non-implementation of the felt needs of the people had given room for anxiety, and in some places anger which had often led to the outbreak of violence.

Again from the FGD and IDI conducted, a potent indicator of social instability was the perceived corruption of the officials of the NDDC by the people. This perception had in some cases e.g. in Igbokoda created a feeling of apathy amongst the teeming unemployed youth.

The results from the study on Research Question Two showed clearly that the level of participation of the people in implementing NDDC programmes of development was rather low. The level of 
participation of the people in physical execution of NDDC projects was slightly below average but better than the level of participation in implementation committee as revealed by Table 6 . With regards to the physical execution of developmental projects, 26.9 percent of the respondents indicated that they occasionally participated while 21.6 percent said that they always did. This slight improvement, in the level of participation can be attributed to the fact that financial incentives such as salaries/wages were instrumental in motivating the people to be involved in the physical execution of the projects.

The number of respondents who indicated that they had never taken part in the physical execution of the NDDC projects was 32.8 percent while 18.7 percent said that they rarely did participate. From the above, it was evident that the level of participation of the people in the physical execution of NDDC projects was average.

In terms of soliciting for financial, material and communal support, Table7 showed that the people's level of participation was below average. 37.6 percent of the respondents indicated that they had never solicited for support for the NDDC programmes while 17.1 percent said that they rarely did. 30.0 percent said that they occasionally did while 15.3 percent said that they always did.

On the whole, the data from Table 7 revealed that the level of participation of the beneficiaries in the determination of their needs vis-à-vis the planning and implementation of the NDDC programme of sustainable development was low. This low level of participation was indicative of the fact that the NDDC already had its objectives which had inspired the chosen programmes to the exclusion of the people's participation in both planning and implementation of the NDDC programmes. NDDC $(2003 ; 16)$ states clearly that one of the commission's responsibilities is the "conception, planning and implementation, in accordance with set rules and regulations, of projects and programmers for sustainable development of the Niger Delta".

Thus the NDDC is simply following its mandate and approach to development which is top-down method of development. This is contrary to Anyanwu, $(1992,1999)$ and Abiona (2009) which argued that the people of a community must be involved in the determination of their felt need in order to identify with the projects of development in their community. The information that was used in the answering this research question is provided in Table 6 showed that only 14.8 percent of the respondents participated in the determination of the projects of the NDDC in their communities while 44 percent said that the choice of the projects was decided solely by the NDDC. This explained why 34.0 percent of the respondents indicated that they were neither involved nor participated in the implementation of the NDDC projects as against 22.7 percent that indicated that they were participating in the project implementation. Also 64.9 percent respondents saw the projects as "their own" meaning that of the NDDC alone while only 16.5 percent of the respondents indentified with the projects.

It is evident from the above data that the beneficiaries of the programme achieved low level participation in the determination of their felt needs as regards planning of and implementation of the programmes. Furthermore, a look at Table 7 provides information on beneficiaries' level of participation in the implementation of choice of project. 38.9 percent of the respondents indicated that they heard never participated in the process. This is a high percentage. 27.4 percent said that they rarely participated in the process, 19.5 percent indicated that they 
occasionally initiated project ideas while 14.2 percent said that they always did. From the above data, it was obvious that the people's level of participation in project initiation was rather low. This means that the NDDC had been solely responsible for the project idea initiation most of the times. This is a topdown approach to development.

\section{Conclusion}

It is clear that environmental degradation problems in the Niger Delta region have risen to a higher level and violence, youthful restlessness, crime and social insecurity in the Niger Delta region which had become a near daily phenomenon are a direct consequence. Many government initiatives to develop the region had suffered failures occasioned by a plethora of reasons. The Federal Government moved to find a lasting solution to the socio-economic travails of the people by bringing sustainable development to the region. The region's problems had recently gained more prominence both in national and international media. The NDDC's success in reducing violence, crimes and social instability in the region is of paramount importance to all stakeholders in the region.

The NDDC's low performance could not reduce the level of social instability in the two states. NDDC's top-down approach to development greatly excluded the people from participating in the identification and implementation of their felt needs and chosen projects. Thus, lack of fulfilment of the urgent and important felt needs of the people is creating anger, anxiety, ill-feeling and restlessness in the people.

The NDDC is, however, hampered by a lot of limitations and constraints such as lack of consultation with the people, inadequate monitoring of projects, a dearth of good roads and difficult terrain and corruption of NDDC officials. The amelioration of these constraints will result in an enhanced and sustained level of performance and accomplishments of its stated objectives. A desirable consequence of this envisaged improvement will be the provision of sustainable development in the area and transformation of the region into an economically prosperous, socially stable, ecologically regenerative and politically peaceful region.

\section{Recommendations}

The findings of this research have profound implications for broad policy formulations aimed at enhancing and sustaining the NDDC's performance of its stated objectives. Thus, in order to ensure the success of the NDDC, the following recommendations are hereby proffered:

1. That an "integrated" approach should be adopted. This is a diffusion of both the "top-down" and "bottom-up" approaches to development. The technocrats are fully equipped with sound technical knowledge of the requirements of development projects but the people in the communities are better placed than the technocrats to know their own felt needs. Communities should form committees or bodies that will be saddled with the responsibility of determining projects that meet the peoples' felt needs.

2. That the NDDC's efforts should be complemented by other stakeholders such as Non-Governmental Organisations, Oil Companies, State Governments and other Private Sector Companies because of the multifaceted needs of the people and the tremendous developmental challenges present in the region, the development of the Niger Delta region is a project that is bigger than the capacity of the NDDC, and so 
should not be left to the government alone.

\section{References}

Abiona, I.A. (2009). Principle and Practice of Community Development in Nigeria, Ibadan, University Press

Anyanwu, C.N. (1992). Principle and Practice of Community Development, Nigerian Experience, Ibadan, Gabesther Educational Publishers

Anyanwu, C.N. (1999). Introduction to Community Development, Ibadan, Gabesther Educational Publishers

Ashton - Jones, (1998). A. The Human Ecosystems of the Niger Delta. Benin City: Environmental Rights Action.

Azaiki, (2003). Inequities in Nigeria Politics. Yenegoa: Treasure Books Ltd.

Bassey, A. and Obari, O.J.O. (1998). Mobil Explains Oil Spillage in Akwa Ibom. The Guardian. January 17th :7

Chokor, B.A. (1992). Environmental Pressure groups and habitat Protection in the developing world: The case of Nigeria. The Environmentalist, 12.3:169-180.

Chokor, B.A. (1993). Government Policy and Environmental Protection in the Developing World; The Example of Nigeria. Environmental Management, 17: $15-30$

Constitutional Rights Project CRP. (1999). Land, oil and Human Rights in Nigeria's Delta Region . 1-66

Dublin-Green, W.F., Nwankwo, J.N and Irechuckwu, D.O. (1998) Effective Regulation and Management of HSE Issues in the Petroleum Industry in Nigeria. Proceedings of SPE International Conference on Health, Safety and Environment on Oil and Gas
Exploration and Production. 7-10 June, 1998. Caracas: SPE. 40.20-26.

Kimani. M.J. (2004). Peace and Conflict transaction in pastoral areas in the IGAD Region. Enhancing the Role of Community - based Approaches and Structures. M.A. Project. University of Nairobi, Kenya.

Nigerian Environmental Study / Action Team (NEST) (1991) Nigeria's Threatened Environment. A National Profile. Ibadan: Intec Printers Ltd.

Obadan, M.I. (2004). Nigerian Economy: Review of the past, reflection on the way forward, Nigerian Tribune Nov 2nd

Odiete, W.O. (1999). Environmental physiology of Animals and Pollution. Lagos: Diversified Resources Limited.

Okonya, E.C., Ajao, E.O., Oyewo, E.O. and Orekoya, T. (1988). Case studies of pollution in the Brackish and Marine Ecosystems in Nigeria. Environmental Issues and Management in Nigeria. P.O. Sada and F.O. Odemerho. Eds. Nigeria: Evans Brothers (Nigeria publishers) Limited. 263-269.

Olaifa, F.E. (2003). Impact of oil Spillage on the Fisheries Resources of Cross River and Akwa Ibom States of Nigeria. Ph.D. Thesis. Dept. of Wildlife and Fisheries Management. University of Ibadan.

Shell Petroleum Development Corporation (SPDC). (2004). Sabotage to oil and gas facilities; an Appeal to Reason. Nigerian Tribune. Oct. 21: A 8

Turcotte, H. (2002). Beneath the Oily Surface. Women's Political Movement Against the State and Oil in Nigeria. Working paper. Retreved Sept 102003 from http://www.nddc research.html 